\title{
Determination of Cognitive Structures of Science Teacher Candidates in Ecology
}

\author{
Zeynep Yüce ${ }^{1, *}$ \\ ${ }^{1}$ Faculty of Education, Kafkas University, Kars, Turkey \\ *Correspondence: Department of Mathematics and Science Education, Faculty of Education, Kafkas University, \\ Kars, Turkey. E-mail: korkmazeynep@gmail.com
}

Received: June 2, 2019

Accepted: July 15, 2019 Online Published: July 17, 2019

doi:10.5430/wje.v9n4p13

URL: https://doi.org/10.5430/wje.v9n4p13

\begin{abstract}
In particular, it is of great importance that teacher candidates are trained to develop awareness of ecology and to protect ecological systems. Because they are the ones who will be educate future generations. Ecology is generally a conceptual field. In this study, it was aimed to determine the conceptual structures related to ecology of science teacher candidates at cognitive level. The study is a qualitative research carried out by the screening model. The study was carried out with the participation of 127 candidates' science teachers. In this study, a word association test (WAT) was used to determine the cognitive structures of science teacher candidates related to "ecology". Content analysis and descriptive analysis methods were used in the analysis of data. In this data, the frequency table has been formed. Based on the frequency tables prepared according to teacher candidates' responses to WAT, concept networks related to ecology have been established. In the preparation of concept networks, cut point technique was used. When we look at the frequency table, it was observed that the key words that teacher candidates associate most with ecology are living places, functional properties of ecology and biotic factors of ecosystems in ecology. The sentences of teacher candidates related to ecology are selected and categorized according to the concepts they contain. When the sentences of teacher candidates related to ecology are examined, it is seen that correct descriptions are found but in many of them there is incomplete information or concept confusion.
\end{abstract}

Keywords: ecology, concept, cognitive structure, word association test, science teacher candidate

\section{Introduction}

In Ancient Greek, oikos was used in the meaning of "home, belongs to home" and logos as "science, research". The word ecology is formed by the combination of these two words. Throughout history, human beings have been intertwined with the subjects of the science of Ecology in order to continue their daily life, even if they define and use it in different ways. However, with the meaning of today, the word ecology was first expressed in 1869 by Ernst Haeckel, a German biologist. Haeckel described ecology as "study of the natural environment, including the relationships between living things and their environment" (Işık, 2008). While ecology was initially seen as a sub-branch in biology, it emerged and developed as a separate discipline in biology from the 1970s onwards. Since then, it has been observed that the world has a functioning that can be easily disrupted and that living things have been affected.

For the last 40-50 years, human beings have been attracted to pollution, population growth, excessive consumption and, depending on these subjects, the protection of natural areas and biodiversity and remedies are sought to prevent the deterioration of functioning systems on Earth. Therefore, more emphasis has been given on ecology education. In particular, it is of great importance that teacher candidates are trained to develop awareness of ecology and to protect ecological systems. Because they are the ones who will be educate future generations.

Ecology is generally a conceptual field and it is difficult to learn in a meaningful way because of the excess of relationships between concepts (Ürey, Şahin, and Şahin, 2011). One of the main reasons for this is that the concepts that are possessed are shaped and understood in their own cognitive structures.

A variety of methods are used to determine the conceptual cognitive structures of individuals about a subject. The word association test (WAT) is one of the oldest and most common methods. In this study, it was aimed to determine the 
conceptual structures related to ecology of science teacher candidates at cognitive level.

\section{Method}

\subsection{Model of Study}

The study is a qualitative research carried out by the screening model. The screening model is a research approach that aims to describe a situation in the past or present as it exists. According to this approach, the subject of the investigation is defined as the individual or the object is in their own circumstances and no attempt is motivated to change or influence in any way (Karasar, 2002). Qualitative research allows perceptions and events to be revealed in a realistic and holistic manner using different methods such as observation, interview and document analysis (Yıldırım and Şimşek, 2013) and can be used to search for answers to questions that are difficult to express with traditional research methods (Büyüköztürk et al., 2011).

\subsection{Sample of Study}

The study was carried out with the participation of 127 candidates' science teachers from 3rd and 4th grade in 2017-2018 academic year at Kafkas University Faculty of Education.

\subsection{Data Collection}

In this study, WAT was used to determine the cognitive structures of science teacher candidates related to "ecology". Word association is a technique designed to determine whether a relationship is established between concepts. In a word association, one or more stimulant words are given and in a short period of time the keywords associated with this stimulant are asked to be written (Atasoy, 2004). This technique can be applied in a few different ways. Bahar, Jonstone and Sutcliffe (1999); Bahar and Özatlı (2003); Kazancı, Doğan Bora and Katırcıŏlu (2005); Ercan, Taşdere and Ercan (2010) gave students more than one stimulus word, while Dikmenli (2010); Ekici and Kurt (2014); Kurtaslan (2018) has tried to determine the cognitive comprehension levels in related subjects by giving a single stimulus word. In this study, only one stimulant word is given. The term "ecology" as a stimulus has been repeated five times at the bottom and teacher candidates have been asked to write the first five words in 30 seconds. Later, teacher candidates were asked to form a sentence about these words they wrote. For this purpose, students have been given 30 seconds. In the literature, the time given to respond to the participants in the word association tests varies. Generally, studies with secondary and university students for 30 seconds (Bahar, Johnstone and Sutcliffe, 1999; Nakiboğlu, 2008; Güneş and Gözüm, 2013; Kaya and Akış, 2015), studies with primary school students were given 60 seconds (Ercan, Taşdere and Ercan 2010; Öner Armağan, 2015; Kurtaslan, 2018). In the present study, the teacher candidates were given a total of 30 seconds to respond to WAT.

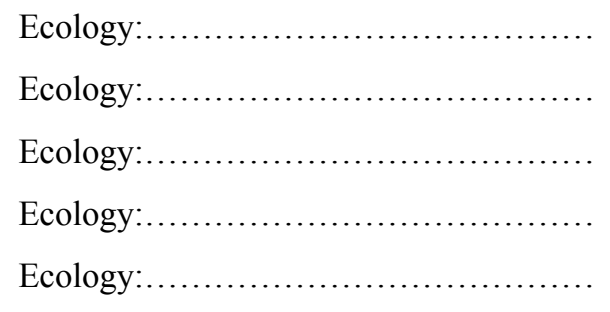

Related Sentence:.

The reason the stimulus is written five times is to prevent the risk of getting away from the stimulant term when the participant is writing down the words he / she has associated with the stimulus. If the participant does not go back in the direction of the stimulus after writing a word, he / she will have to write the words associated with the previous words he / she wrote on the lower side instead of the stimulant term. This situation may be reversed to the purpose of the test. The warning term has been repeated five times to prevent this situation.

\subsection{Analysis of the Data}

Content analysis and descriptive analysis methods were used in the analysis of data. In order to evaluate the data obtained from the word association test, the teacher candidates' responses to the stimulus word were examined carefully. In this part of the study, words are categorized using semantic relationship criteria and the frequency of words is calculated (Daskolia, Flogaitis, and Papageorgiou, 2006; Kostova and Radoynovska, 2008). In this data, the frequency table has been formed. These keywords in the generated frequency table are defined as sub-concept categories. Then, the related sub-concepts were brought together and the upper concept categories were formed. 
Based on the frequency tables prepared according to teacher candidates' responses to WAT, concept networks related to ecology have been established. In the preparation of concept networks, cut point technique was used which was revealed by Bahar, Jonstone and Sutcliffe (1999). According to this technique, in the frequency table, the word association test for the stimulus word for the most given answer is taken as a breakpoint below the word 3-5 number and the answers above the frequency of this answer are written to the first part of the concept network. Later, the cut point is pulled down at certain intervals and the process is continued until all the keywords appear. As a result of the application, it was seen that the maximum frequency in the words associated with ecology was 46 . The first cutoff point, which is five below 46 frequencies, is defined as the frequency range of 42 and above. The same procedure has been applied until all the words given to the stimulus are revealed in conceptual networks (Ercan, Taşdere, and Ercan, 2010). This technique has been used in many studies in the literature (Bahar, Jonstone and Sutcliffe, 1999; Ercan, Taşdere and Ercan, 2010; Öner Armağan, 2015; Canbazoğlu Bilici, 2016). Finally the sentences of teacher candidates related to ecology are selected and categorized according to the concepts they contain. The literature about the sentences was examined and then the literature about the sentences written by the teacher candidates was compared.

\section{Findings}

As a result of data analysis, a total of seven upper concept categories and forty-six lower concept categories were created for the concepts associated with ecology. The frequency and percentage distributions of the concepts in each category are listed in Table 1.

Participants associated 46 different concepts related to ecology. The upper concept, which has the most frequency from the related concepts, is related to the living place $(\mathrm{f}=141)$. In this category, participants focused on the concepts of environment, habitat, nature, ecosystem, world, forest and biome. In the upper concept of the living place, the first three concepts that the participants repeat most are the environment $(\mathrm{f}=46)$, habitat $(\mathrm{f}=28)$ and nature $(\mathrm{f}=28)$. These results showed that teacher candidates have a direct relationship with ecology, the most environment, habitat and nature. The environment is an environment in which living things are interacted with other living creatures and non-living organisms and sustains their vital activities (Erdoğan, 2016). Habitat is a place where a species can sustain its vital activities as the best in its ecological sense and it is the easiest place to find when it is searched (Görür, 2011). So it's the address of a living creature. Nature, with the definition of the Turkish Language Institution (URL1) means "the environment which has not been altered by the human hand and protects its natural structure." Therefore, when we look at the concepts in this category that teachers associate with ecology, it is seen that all of them are environments in which living things continue their lives. It was found appropriate to combine these concepts as the upper concept of the living place of the participants.

The second category shows that teacher candidates relate the functional characteristics of ecology and ecology ( $\mathrm{f}=118$ ). In the upper concept of functionality, participants focused on balance, niche, cycle, food chain, relationship, order, system, interaction, chain, diversity, capacity, war, community, togetherness, food network, harmony and competition concepts. The first three concepts that the participants repeated most were balance $(\mathrm{f}=33)$, niche $(\mathrm{f}=18)$ and cycle $(\mathrm{f}=14)$. These results showed that teachers had a direct relationship between ecology and balance, niche and cycle. In ecology, balance is a dynamic state where ecosystems, species and genetic diversity remain largely stable. So the steady continuation of the number of species in ecosystems is an ecological balance. From the smallest to the largest, from the bottom of the food chain to the top, all the conditions for the survival of life are called ecological equilibrium (Kıyıc1, 2009). Living things have a variety of responsibilities and therefore a variety of functions to sustain their lives. The niche also refers to all responsibilities and activities that a living being has to do in its environment (Görür, 2011). In order for ecosystems to maintain their natural balance and maintain their existence, the substance and energy consumed by the living creatures in the ecosystem must be returned to the ecosystem. This event is called a substance cycle (Uzun, 2016). Therefore, when we look at the concepts in this category associated with ecology, all of them are ecological factors that are essential for the survival of living things in a dynamic and healthy ecosystem. It was found appropriate for the participants to combine the concepts related to these functional factors of ecology as the upper concept of functionality. 
Table 1. Frequency and Percentage Distributions of Concepts Associated with Ecology

\begin{tabular}{|c|c|c|c|c|c|c|}
\hline $\begin{array}{l}\text { Upper } \\
\text { Concept }\end{array}$ & $\begin{array}{l}\text { Sub } \\
\text { Concepts }\end{array}$ & $\begin{array}{l}\text { (Keywords) } \\
\text { Frequencies of Sub Concepts }\end{array}$ & $\begin{array}{l}\text { Sub Concept } \\
\text { Total } \\
\text { Frequency }\end{array}$ & $\begin{array}{l}\text { Sub } \\
\text { Concept } \\
\text { Total } \\
\text { Percent }\end{array}$ & $\begin{array}{l}\text { Total } \\
\text { Frequency }\end{array}$ & $\begin{array}{l}\text { Total } \\
\text { Percentage }\end{array}$ \\
\hline
\end{tabular}

\begin{tabular}{|c|c|c|c|c|c|c|c|c|c|c|}
\hline & & $\stackrel{\circ}{\circ}$ & $\begin{array}{l}\overrightarrow{0} \\
i \\
i\end{array}$ & $\begin{array}{l}\overrightarrow{0} \\
\dot{0}\end{array}$ & $\begin{array}{l}\overrightarrow{0} \\
\dot{0} \\
\dot{+}\end{array}$ & is & & & & \\
\hline \multirow{7}{*}{$\begin{array}{l}\text { Living } \\
\text { Place }\end{array}$} & Environment & 23 & 12 & 7 & 3 & 1 & 46 & 9.7 & \multirow{7}{*}{141} & \multirow{7}{*}{$\% 29.6$} \\
\hline & Habitat & 6 & 3 & 9 & 6 & 4 & 28 & 5.9 & & \\
\hline & Nature & 6 & 8 & 7 & 4 & 3 & 28 & 5.9 & & \\
\hline & Ecosystem & 7 & 4 & 2 & 7 & & 20 & 4.2 & & \\
\hline & World & & 2 & 5 & 5 & 1 & 13 & 2.7 & & \\
\hline & Forest & 1 & & 1 & 1 & 1 & 4 & 0.8 & & \\
\hline & Biome & & 1 & 1 & & & 2 & 0.4 & & \\
\hline \multirow{17}{*}{ Functionality } & Balance & 11 & 7 & 7 & 4 & 4 & 33 & 6.9 & \multirow{17}{*}{118} & \multirow{17}{*}{$\% 24.8$} \\
\hline & Niche & 2 & 6 & 5 & 3 & 2 & 18 & 3.8 & & \\
\hline & Cycle & 3 & 5 & & 3 & 3 & 14 & 2.9 & & \\
\hline & Food Chain & 2 & & 1 & 5 & 1 & 9 & 1.9 & & \\
\hline & Relationship & 2 & 2 & 2 & & & 6 & 1.3 & & \\
\hline & Order & 1 & 1 & 2 & 1 & 1 & 6 & 1.3 & & \\
\hline & System & & 3 & 3 & & & 6 & 1.3 & & \\
\hline & Interaction & 2 & & 1 & 1 & & 4 & 0.8 & & \\
\hline & Chain & 1 & 1 & 1 & & & 3 & 0.6 & & \\
\hline & Diversity & 1 & & 1 & 1 & & 3 & 0.6 & & \\
\hline & Capacity & 1 & & 1 & & 1 & 3 & 0.6 & & \\
\hline & War & & & 1 & & 2 & 3 & 0.6 & & \\
\hline & Community & 1 & 1 & & & & 2 & 0.4 & & \\
\hline & Togetherness & 1 & & 1 & & & 2 & 0.4 & & \\
\hline & Food Network & & 1 & & & 1 & 2 & 0.4 & & \\
\hline & Harmony & & 2 & & & & 2 & 0.4 & & \\
\hline & Competition & & & 1 & & 1 & 2 & 0.4 & & \\
\hline \multirow{8}{*}{$\begin{array}{l}\text { Biotic } \\
\text { Factor }\end{array}$} & Live & 13 & 13 & 7 & 4 & 4 & 41 & 8.6 & \multirow{8}{*}{101} & \multirow{8}{*}{$\% 21.2$} \\
\hline & Human & 4 & 1 & 6 & 4 & 6 & 21 & 4.4 & & \\
\hline & Species & 1 & 3 & 1 & 3 & 5 & 13 & 2.7 & & \\
\hline & Animal & 4 & 4 & & 2 & & 10 & 2.1 & & \\
\hline & Plant & 2 & 2 & 4 & 2 & & 10 & 2.1 & & \\
\hline & Decomposer & 1 & 1 & & & & 2 & 0.4 & & \\
\hline & Bacterium & & & 1 & 1 & & 2 & 0.4 & & \\
\hline & Producer & & 2 & & & & 2 & 0.4 & & \\
\hline \multirow{2}{*}{ Living } & Life & 8 & 4 & 7 & 5 & 2 & 26 & 5.5 & \multirow{2}{*}{32} & \multirow{2}{*}{$\% 6.7$} \\
\hline & Natural Life & 1 & 1 & 1 & 2 & 1 & 6 & 1.3 & & \\
\hline \multirow{6}{*}{$\begin{array}{l}\text { Abiotic } \\
\text { Factor }\end{array}$} & Lifeless & & 5 & 3 & 3 & 1 & 12 & 2.5 & \multirow{6}{*}{30} & \multirow{6}{*}{$\% 6.3$} \\
\hline & Soil & 1 & & 3 & 1 & 1 & 6 & 1.3 & & \\
\hline & Sun & 1 & 2 & & 1 & & 4 & 0.8 & & \\
\hline & Air & & 1 & 2 & & & 3 & 0.6 & & \\
\hline & Water & & 1 & 1 & & 1 & 3 & 0.6 & & \\
\hline & Climate & & & 2 & & & 2 & 0.4 & & \\
\hline \multirow{4}{*}{ Society } & Population & 4 & 5 & 3 & 6 & 3 & 21 & 4.4 & \multirow{4}{*}{28} & \multirow{4}{*}{$\% 5.9$} \\
\hline & Community & 1 & & & 1 & 1 & 3 & 0.6 & & \\
\hline & Fauna & 1 & 1 & & & & 2 & 0.4 & & \\
\hline & Flora & & 1 & & & 1 & 2 & 0.4 & & \\
\hline \multirow{5}{*}{ Science } & Science Branch & 7 & 4 & 5 & 4 & 2 & 22 & 4.6 & & \\
\hline & Biology & 1 & 1 & 1 & 1 & & 4 & 0.8 & 26 & $\% 5.5$ \\
\hline & Number of respo & ses ass & ciated & with $\mathrm{e}$ & ology & & & & 476 & $\% 75$ \\
\hline & Number of respo & ses not & associ & ted wi & ecolo & & & & 159 & $\% 25$ \\
\hline & Total number of & spons & & & & & & & 635 & $\% 100$ \\
\hline
\end{tabular}


The third category shows that teacher candidates associate biotic factors $(\mathrm{f}=101)$ within ecology and ecology. Biotic factors in the upper concept, participants focused on the concept of live, human, species, animal, plant, decomposer, bacteria and producer. The first three concepts that the participants repeated most were live ( $\mathrm{f}=41)$, human $(\mathrm{f}=21)$ and species $(\mathrm{f}=13)$. These results show that teacher candidates have a direct relationship between ecology and live, human and species. Ecosystems are composed of biotic (live) and abiotic (lifeless) factors. All biotic and abiotic factors affecting the life of an organism directly or indirectly, positively or negatively can be defined as ecological factors (Görür, 2011). It forms a species that comes from the same ancestor, which is structurally similar to each other, has the same homologous structures and gives infertile offspring when they mate. Therefore, when we look at the concepts in this category that teacher candidate's associate with ecology, it is seen that all ecological factors are the factors of vitality. It was found appropriate to combine these concepts with the biotic factor upper concept of the participants.

The fourth category shows that teacher candidates associate living with ecology ( $\mathrm{f}=32$ ). In the upper concept of living, they focused on the concepts of life ( $\mathrm{f}=26)$ and natural life $(\mathrm{f}=6)$. It has been observed that teacher candidates have a direct relationship between ecology and living. Living is the definition of the Turkish language institution (URL1) and means "the time between birth and death, life span, lifetime". Natural life is a natural life that is suitable for nature. Therefore, when we look at the concepts of life and natural life in this category associated with ecology, it was found appropriate to combine both of them as the upper concept of living.

The fifth category shows that prospective teachers associate the abiotic factors $(\mathrm{f}=30)$ within the ecology and ecology. Within the concept of abiotic factors, the participants focused on the concepts of lifeless, soil, sun, air, water and climate. The first three concepts that the participants repeated most were lifeless ( $\mathrm{f}=12)$, soil $(\mathrm{f}=21)$ and sun ( $\mathrm{f}=13$ ). These results show that teachers have a direct relationship between ecology and lifeless, earth and sun. In this category, soil, sun, air, water and climate are among the lifeless factors of ecosystems. Therefore, when we look at the concepts in this category that teachers associate with ecology, it is seen that all ecological factors are lifeless factors. It was found appropriate to combine these concepts with the concept of abiotic factor upper.

The sixth category shows that teacher candidates associate their societies with ecology ( $\mathrm{f}=28)$. In the upper concept of the society, the participants focused on population ( $\mathrm{f}=21)$, community $(\mathrm{f}=3)$, fauna $(\mathrm{f}=2)$ and flora $(\mathrm{f}=2)$. These results showed that teachers candidates had a direct relationship between ecology and population. The population is a community formed by individuals belonging to a single species living in a particular time and in a characteristic area (Görür, 2011; Yurtsever, 2011; Akman, Ketenoğlu, Kurt and Yiğit, 2012). The community of multiple living populations interacting with each other in the same space at a given time is called community (Görür 2011; Akman, Ketenoğlu, Kurt, and Yiğit, 2012). In a given time, animal populations in a given area are called fauna and flora. Therefore, it is seen that when we look at the concepts in this category that teachers candidates associate with ecology, all of them are related to the society. It was found appropriate to combine these concepts as the upper concept of the society.

The latest category shows that teachers candidates associate science with ecology ( $f=26)$. In the upper concept of science, the participants focused on science branch $(\mathrm{f}=22)$ and biology $(\mathrm{f}=4)$. These results show that teachers' candidates have established a direct relationship between ecology and science. Ecology is a branch of science that explores organisms and their relationships with their environment. In the same way, biology is a branch of science that examines the origins, structures and vital functions of all living things. The most important points of both ecology and biology are their meeting in science. Therefore, when we look at the concepts of science and biology in this category, which are associated with ecology, we find it appropriate to combine both of them as science upper concept.

Of the 127 teacher candidates, 43 were living place, 28 were functional factors of ecology, 25 were biotic factors, 9 were living, 8 were science, 6 were societies and 2 were abiotic factors related first words in the word association test to the upper concept category. Six teachers were unable to write any of the concepts related to ecology as the first word. In the first word, the teacher candidates for the word association test put forth these three concepts in the sub-concepts by writing environment $(\mathrm{f}=23)$, live $(\mathrm{f}=13)$ and balance $(\mathrm{f}=11)$ as the first word. This result shows that $37 \%$ of teacher candidates are considered to be ecologists, and that these three concepts are the first ones to be remembered in their minds.

The cognitive structures of science teacher candidates for ecology are given in the following ways. 


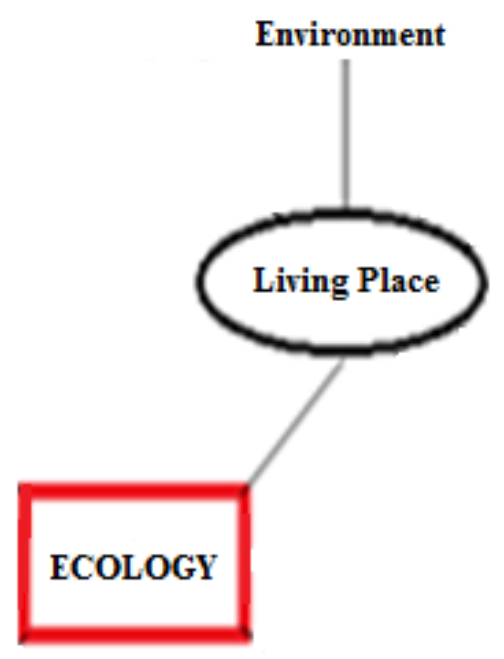

Figure 1. Cognitive Concept Networks with Cutting Point Frequency Range 42 and Above of Teacher Candidates

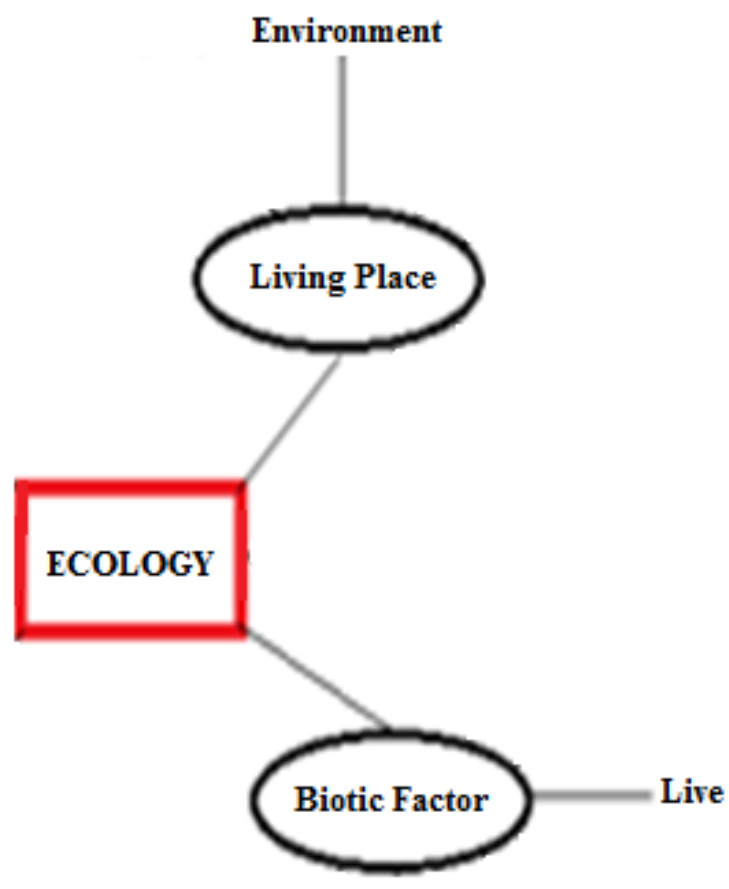

Figure 2. Cognitive Concept Networks with Cutting Point Frequency Range 37-41 Related to Ecology of Teacher Candidates 


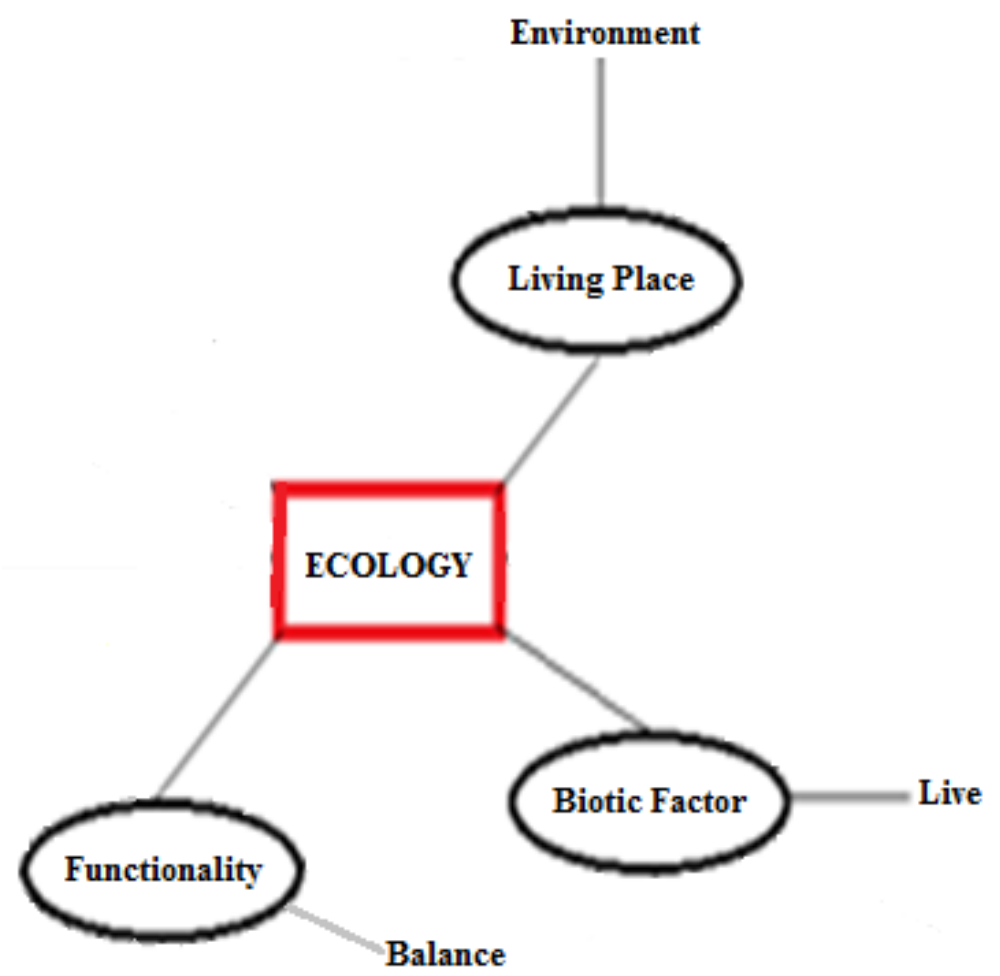

Figure 3. Cognitive Concept Networks with a Frequency Range of 32-36 Cutting Point Related to Ecology of Teacher Candidates

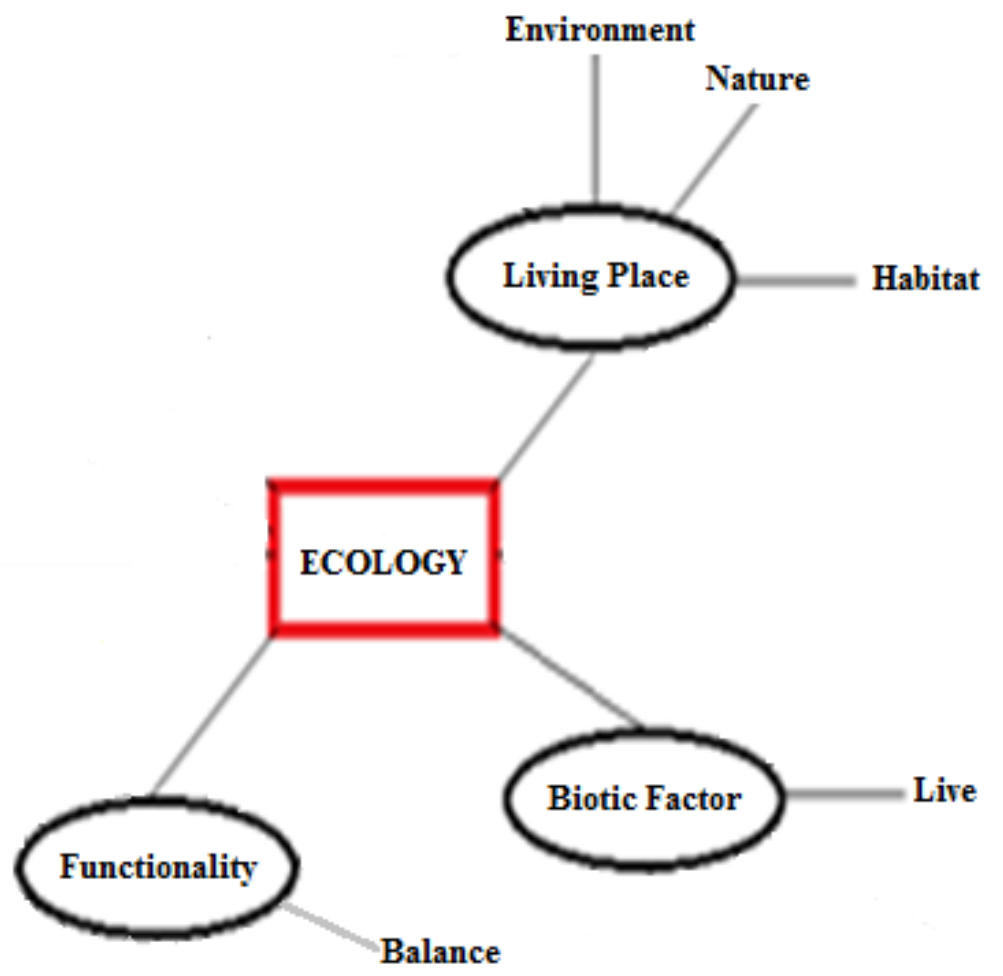

Figure 4. Cognitive Concept Networks with Cutting Point Frequency Range 27-31 Related to Ecology of Teacher Candidates 


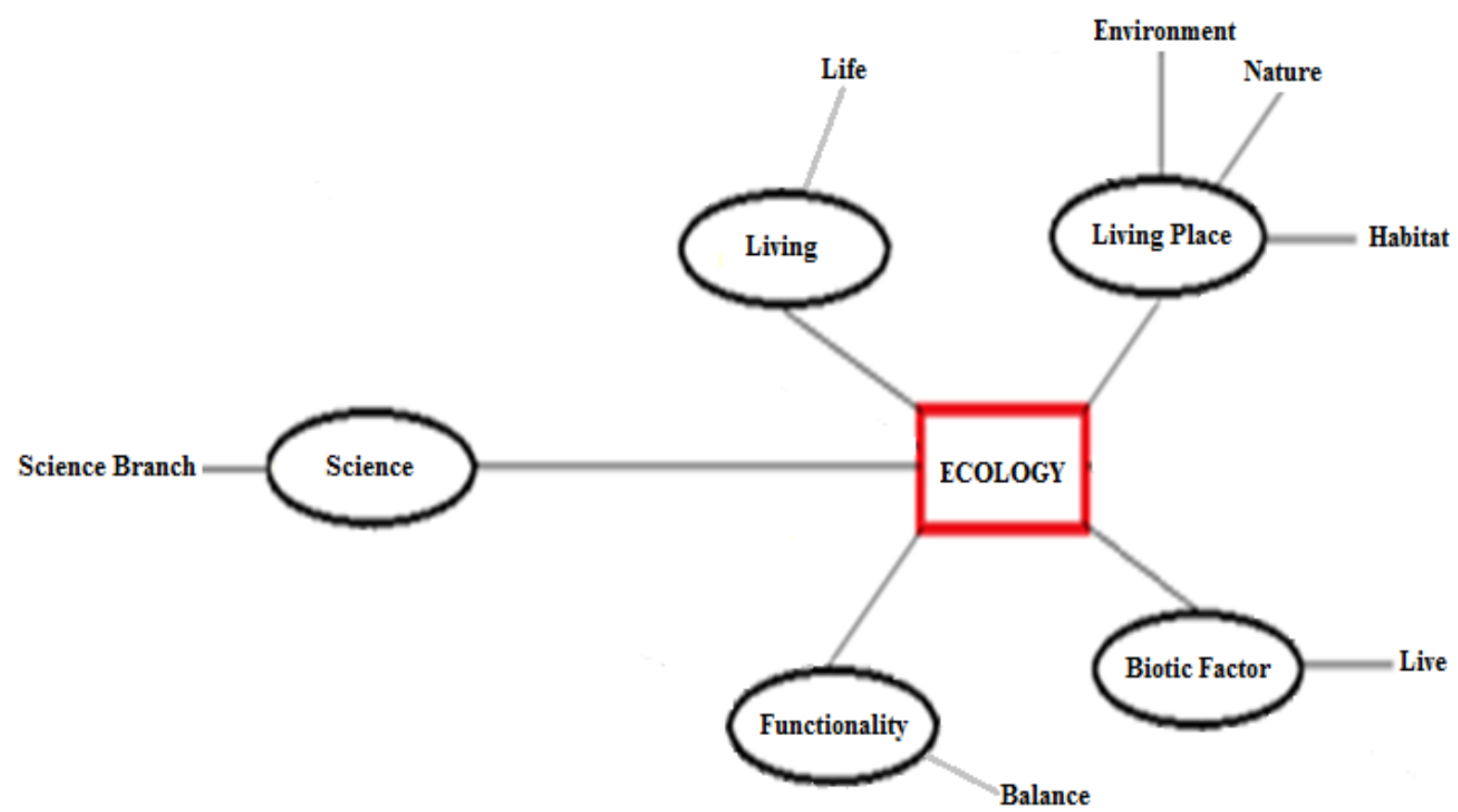

Figure 5. Cognitive Concept Networks with Cutting Point Frequency Range 22-26 Related to Ecology of Teacher Candidates

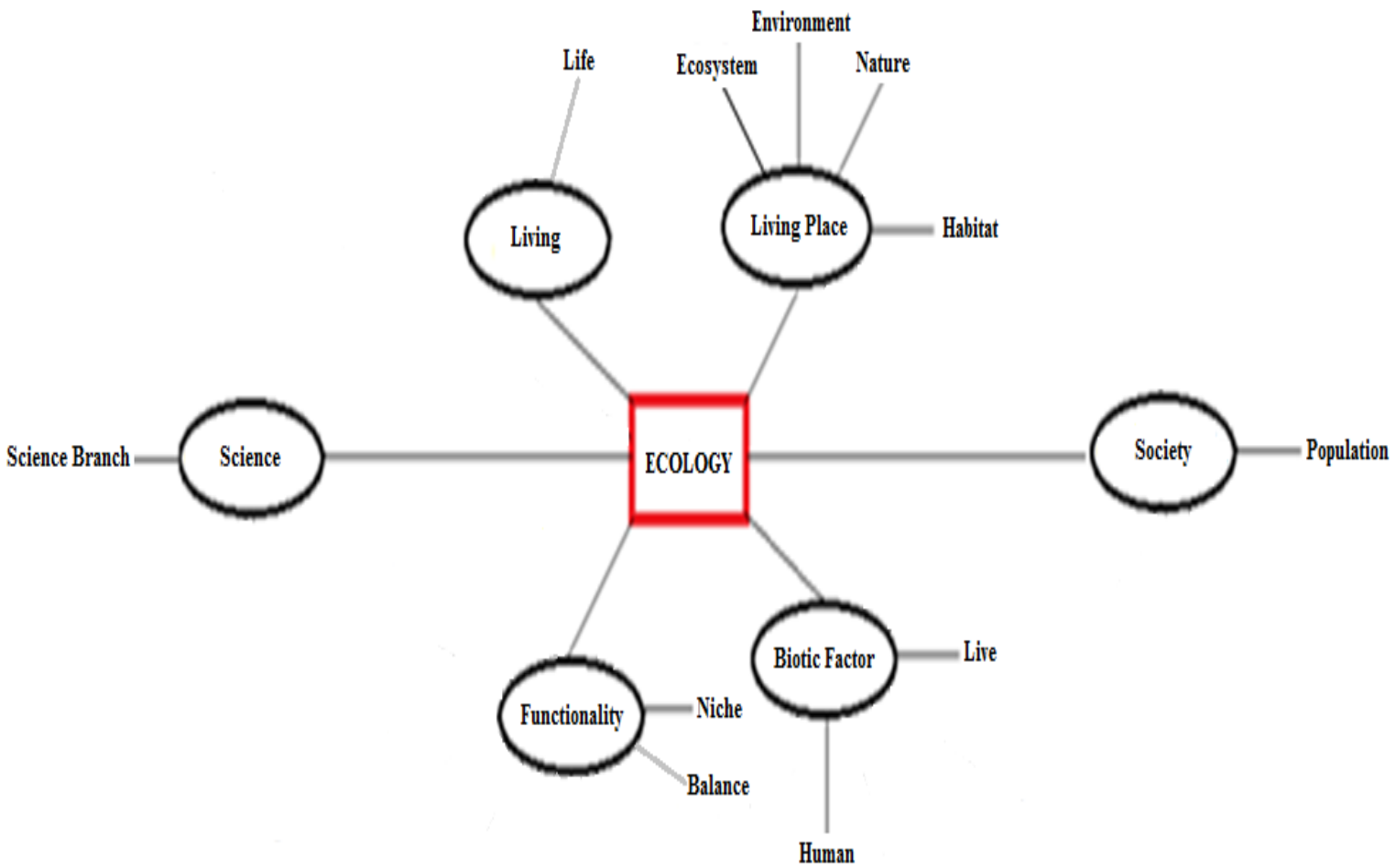

Figure 6. Cognitive Concept Networks with Cutting Point Frequency Range 17-21 Related to Ecology of Teacher Candidates 


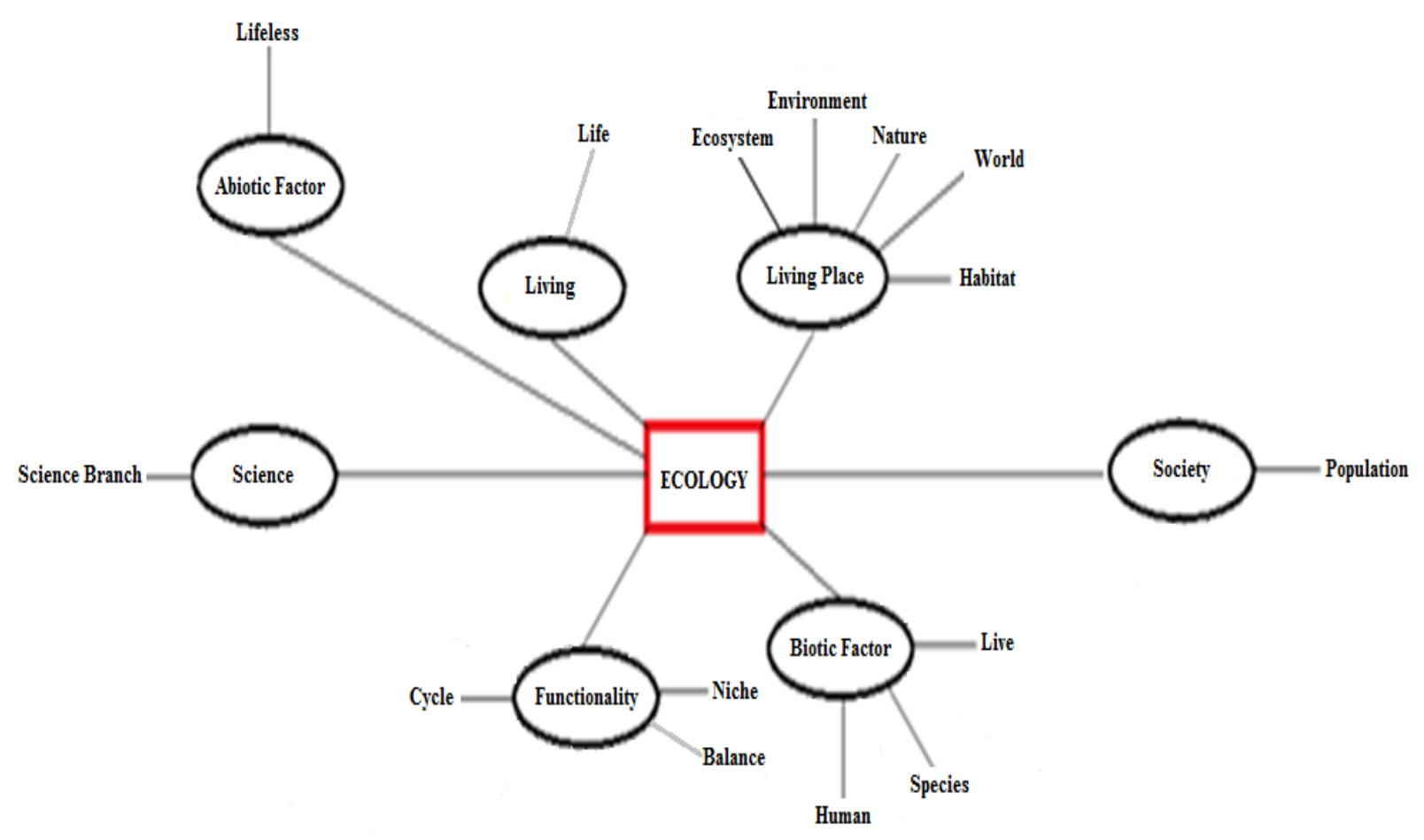

Figure 7. Cognitive Concept Networks with Cutting Point Frequency Range 12-16 Related to Ecology of Teacher Candidates

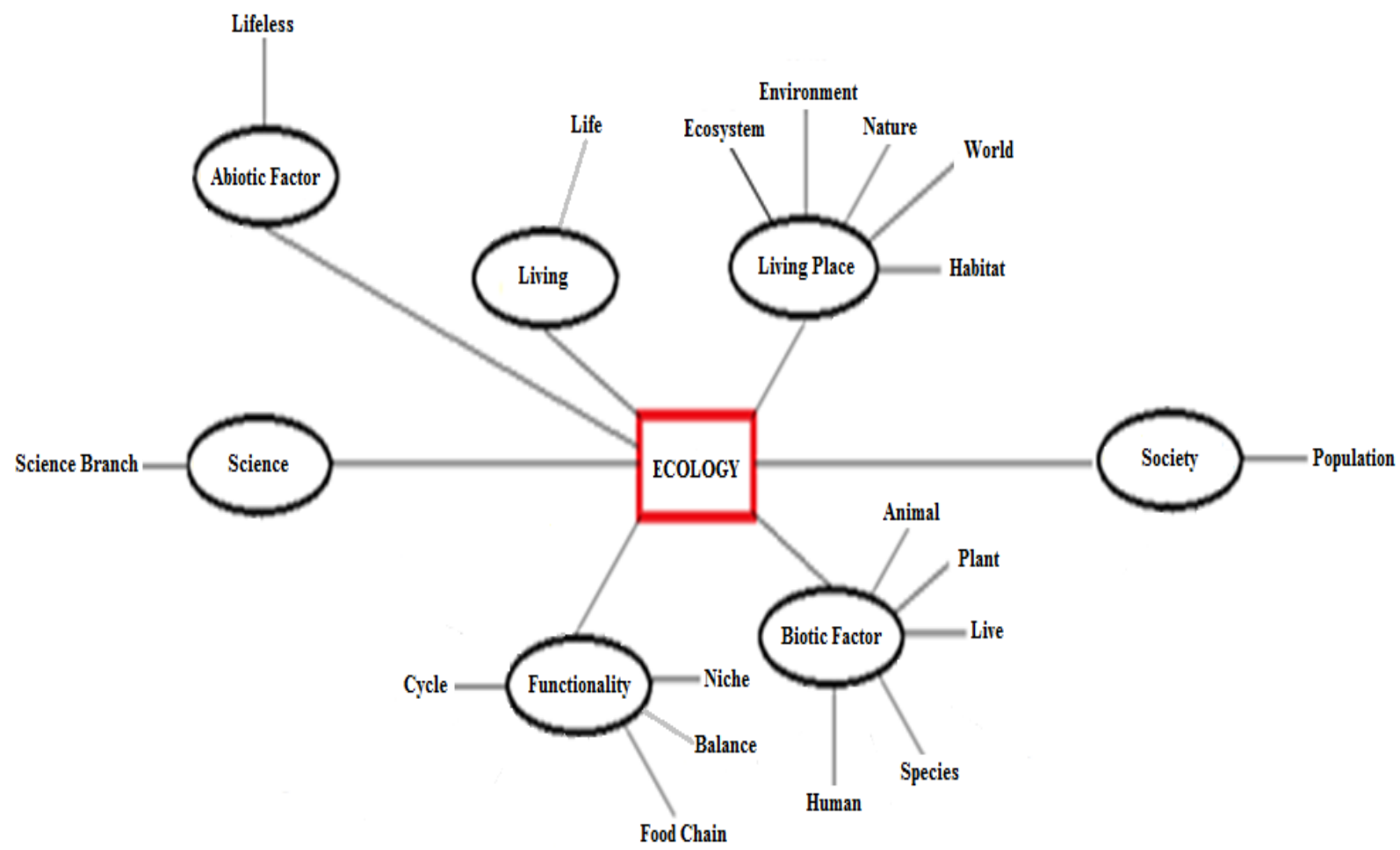

Figure 8. Cognitive Concept Networks with Cutting Point Frequency Range 7-11 Related to Ecology of Teacher Candidates 


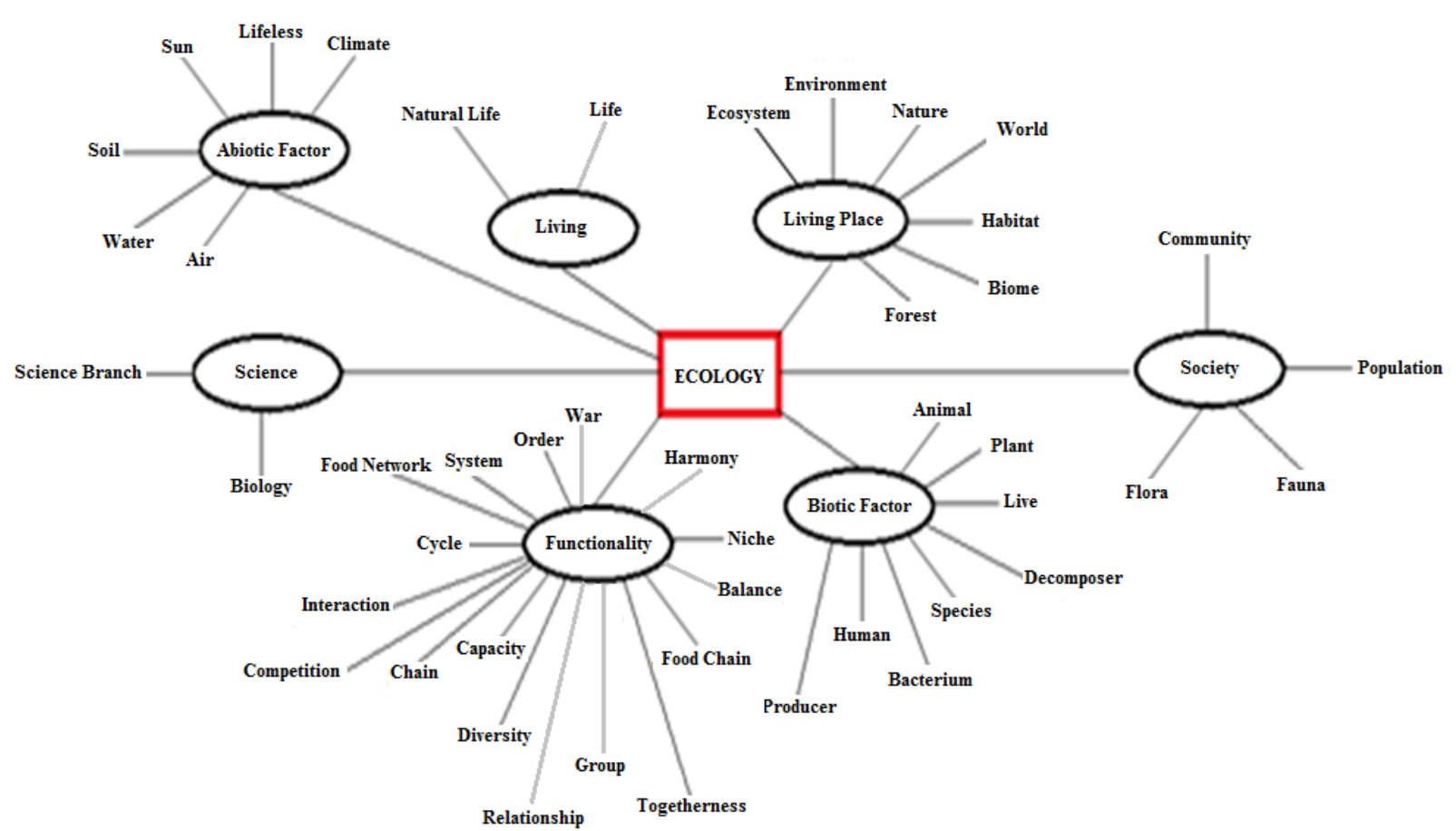

Figure 9. Cognitive Concept Networks with Cutting Point Frequency Range 2-6 Related to Ecology of Teacher Candidates

The concepts that teacher candidates associate with ecology and the sentences they form using these concepts are given in Table 2.

Table 2. Concepts Associated with Ecology of Teacher Candidates and Correct, Incomplete or Alternative Expressions Related to These Concepts

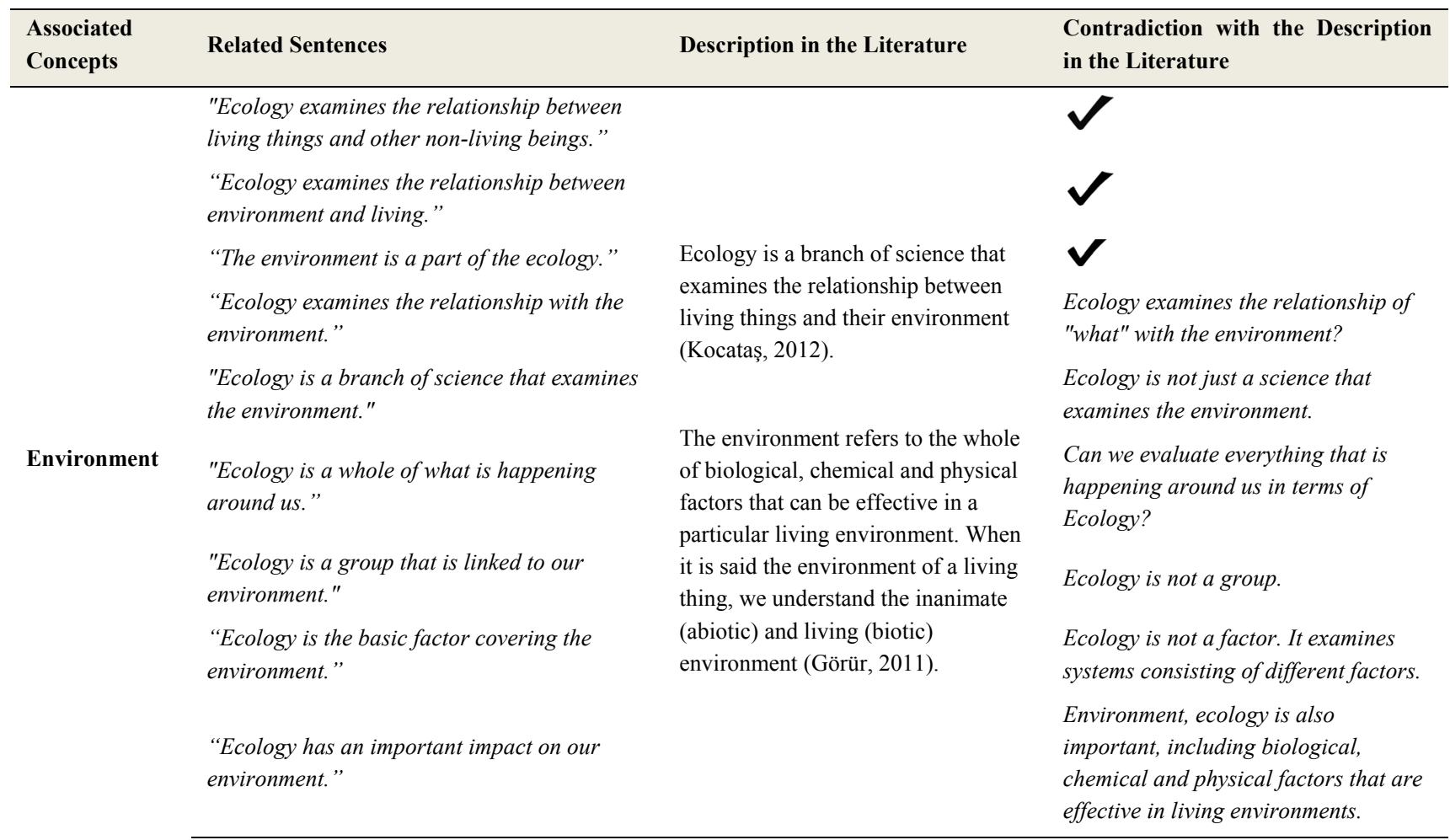


"Ecology deals with the environment we live in."

"Ecology is left the environment and the world better."

"Ecology is a branch of science that explores the interaction of living beings with each other and with their environment."

"Ecology is the science that examines the relationship between living and non-living."

"Ecology covers every component of living non-living."

"Ecology is the structure of living and non-living beings."

Living

"Ecology is a branch of science that examines living things."

"Ecology examines the lifestyle of living things."

"Ecology examines the relationship between living things."

"Ecology is the interaction of living things in the world."

"Ecology is a life of living things."
Ecology is a branch of science that examines the relationships between living things and their environment (Kocataş, 2012).
Doesn't it deal with the environment that we don't live in?

Ecology is a branch of science that handles relationships as they exist. How can "environment and the world" be better left with ecology?

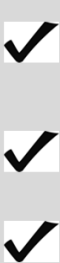

Ecology is not a structure. Ecology is a branch of science where living and non-living beings are dealt with together.

Ecology is not just a branch of science that examines living things.

Ecology is not just a branch of science that examines living things.

Ecology is not just a branch of science that examines living things.

The interaction of living things with each other is a situation that occurs within ecological (natural) systems. Ecology is a science that examines them.

Ecology is a branch of science that also examines living things life.

There is a balance in ecological (natural) systems or ecosystems.

"Ecological balance in nature protects living beings life."

"Ecology is a lifestyle that includes natural balance for our world."

"The place of ecology is important in the balance of life "

Balance

"Ecological balance is like mutualism among living things."

Natural systems have the power to repair and rearrange themselves when they are not out of repair power (Kocataş, 2012).

"Without an ecological balance, life will be destroyed."
In natural systems, there are dynamic and continuous relationships between living and non-living. These relationships occur in a certain order and balance. This state of nature is called ecological balance or natural balance. (Kocataş, 2012).
Ecology is not a lifestyle. Ecological life is a lifestyle.

Ecology is a branch of science. This scientific branch examines the dynamic and persistent relationships between the living and the non-living. These relationships occur in a certain order and balance.

Mutualism is a double-sided advantage. Ecological balance is not always seen as mutualism.

When an ecological balance breaks down, life doesn't disappear suddenly. Different lives emerge in the direction of establishing the balance. Natural systems have the power to repair and reorganize themselves.

Nature Everything that happens in nature is in
ecology."
ecology." 


\begin{tabular}{|c|c|}
\hline & $\begin{array}{l}\text { "Ecology is a branch of science that } \\
\text { encompasses nature." }\end{array}$ \\
\hline \multirow{3}{*}{ Habit } & "Ecology is a collection of habitats." \\
\hline & "Ecology and habitat are a whole." \\
\hline & $\begin{array}{l}\text { "There are habitats that have adapted to } \\
\text { different ecological regions." }\end{array}$ \\
\hline \multirow{7}{*}{ Life } & $\begin{array}{l}\text { "Ecology is a science that concerns everything } \\
\text { in our lives." }\end{array}$ \\
\hline & "Ecology deals with the life of living things." \\
\hline & "Ecology is intertwined with natural life." \\
\hline & $\begin{array}{l}\text { "Ecology is the habitat of living and } \\
\text { non-living." }\end{array}$ \\
\hline & $\begin{array}{l}\text { "Ecology is the common area of many living } \\
\text { things as life "." }\end{array}$ \\
\hline & $\begin{array}{l}\text { "Ecology is a way of life with living and } \\
\text { non-living beings." }\end{array}$ \\
\hline & $\begin{array}{l}\text { "Ecology is the center of life for living } \\
\text { things." }\end{array}$ \\
\hline
\end{tabular}

"Ecology is an important branch of science that exists in our lives."

"Ecology is a branch of science that examines living and non-living things relationships."

"Ecology is environmental science." and its field of study is very broad. Ecology can also be included in the study areas of other natural sciences (Kocataş, 2012).

It is the place where the individuals of a species can maintain their vital activities in the best way (can be fed, breed or shelter) and the most easily found when the species is searched (Görür, 2011).

The living area of the community can also be defined as a biotope (Görür, 2011).

\section{Ecology is a branch of science that} examines the relationships between living things and their environment. (Kocataş, 2012).

Ecology is a sub-branch of biology which is one of the natural sciences and its field of study is very broad. Ecology can also be included in the study areas of other natural sciences (Kocataş, 2012).

The ecosystem is a functional ecological system consisting of living things and non-living environment (Işık, 2008).

Ecology is a branch of science that examines the relationships between living things and their environment (Kocataş, 2012).

Ecology is not a simple science alone, but an interdisciplinary science in which different disciplines are evaluated together (Görür, 2011).

Although some researchers expressed that ecology and environmental science are in the same sense, environmental science includes other disciplines along with ecology (Kışlalığlu and Berkes, 1990).

The term "environmental science" in Turkish is used as "environmental science" in English. The term "ecology"differs from the science in which the term "ecology" is expressed in Turkish.For example;
The biotope could be a community of habitats.

The habitat and the species can be considered as a whole.

There are living things that adapt to different ecological regions and they live in habitats that are suitable for them.

\section{$\checkmark$}

Ecology is not only interested in life of living beings.

Ecology is a branch of science. Natural life is also a field of ecology science.

"Ecology" is used in place of the concept of "ecosystem" and is stated as living space (environment) of living beings.
"It is formed by the word eco-environment and loji-science."
Although some researchers expressed that ecology and environmental science are in the same sense, environmental science includes other disciplines along with ecology. Ecology and environmental science do not mean the same. 
While ecology is based on any living or living societies, human being is the center for environmental science (Sevgi, 2015).

"There are structures in ecology that make up
the ecosystem."
"Ecosystem
non-living things factors."

"People are very important for the balance of Ecology."

The ecosystem is a functional ecological system consisting of living things and non-living environment (Işık, 2008).

Human being can control the activities of other living things, guide them, and greatly change the environmental conditions according to its needs. As a result of this, we are confronted with a major biotic

Human

"Human beings are a part of ecology."

"Human being provides the order of ecology."

"Ecology is effective in human life and live."

"In ecology, communities formed by the same
species are populations."

A group of individuals living in a specific area and belonging to the same type is known as populations (Kaya and Işık, 2008).

All elements in the biosphere move from environment to living things and from living things to environment again. Usually called a cycle because it follows a circular path (Güleryüz, Arslan and Gökçeoğlu, 2008).
Ecosystems are ecological systems consisting of living and non-living beings. Ecology is a branch of science that examines ecosystems.

Humans are an important element for the balance of ecological systems or ecosystems.

Humans are part of the ecological (natural) systems

Human beings are a factor that tries to change other living things and environmental conditions in the ecological systems to a great extent according to their needs.

Ecological (natural) systems are effective in human life and live.

Population is the communities that live in a specific area and that are formed by individuals of the same type.

In ecological (natural) systems or ecosystems, material cycles take place, including living and non-living beings. Ecology examines these cycles.

The transfer of food and energy from primary producers to primary, secondary... consumers and saprophytes defined as a food chain, and many food chains occur spontaneously in nature (Uzun, 2016).

One of the important elements that make up the ecosystem is consumers. Consumers are mostly composed of animal species (Gökmen, Kubanç, Kubanç and Ateş Sönmezoğlu, 2011).

"Ecology is environmental science, so it examines animals."

Ecology is a branch of science that examines the relationship between living things and their environment. (Kocataş, 2012).
Plant
"Ecology examines the structure and life of plants."

Although some researchers say that ecology and environmental science are the same, environmental science also includes other disciplines along with ecology (Kışlalığlu and
Ecology does not prepare the environment for the food chain. In ecological systems, food chains are established spontaneously. Ecology Science also examines them.

Ecology does not only examine animals and their environment.

Ecology and environmental science do not have the same meanings. However, ecology also examines animals and their behavior.

Ecology does not only examine plants and their structures. 
Berkes, 1990).

\begin{tabular}{|c|c|c|c|}
\hline Interaction & $\begin{array}{l}\text { "Ecology examines the interaction of living } \\
\text { things between them and their environment." }\end{array}$ & $\begin{array}{l}\text { Ecology is a branch of science that } \\
\text { examines the relationships between } \\
\text { living things and their environment } \\
\text { (Kocataş, 2012). } \\
\text { Living things affect their } \\
\text { environment as they are influenced } \\
\text { by their environment (Kocataş, } \\
\text { 2012). }\end{array}$ & \\
\hline Relationship & $\begin{array}{l}\text { "Ecology covers the relationships between } \\
\text { living and non-living." } \\
\text { "Ecology is the relationship between living } \\
\text { things." }\end{array}$ & $\begin{array}{l}\text { The basis of ecology is the } \\
\text { relationships of living beings with } \\
\text { each other and their inanimate } \\
\text { environment (Kocataş, 2012). }\end{array}$ & $\begin{array}{l}\text { Ecology is not the relationship } \\
\text { between "living things". It is a branch } \\
\text { of science that examines the relations } \\
\text { of living things with each other and } \\
\text { with their environment. }\end{array}$ \\
\hline Order & $\begin{array}{l}\text { "Ecology is a regular survival of living } \\
\text { things." }\end{array}$ & $\begin{array}{l}\text { Ecology is a branch of science that } \\
\text { examines the relationships between } \\
\text { living things and their environment } \\
\text { (Kocataş, 2012). } \\
\text { In natural systems, there are dynamic } \\
\text { and continuous relationships between } \\
\text { living and non-living. These } \\
\text { relationships occur in a certain order } \\
\text { and balance (Kocataş, 2012). }\end{array}$ & $\begin{array}{l}\text { In ecological (natural) systems or } \\
\text { ecosystems, there are dynamic and } \\
\text { continuous relationships between } \\
\text { living and inanimate. These } \\
\text { relationships occur within a certain } \\
\text { order. Ecology examines the whole of } \\
\text { these regular relationships. }\end{array}$ \\
\hline Chain & "Ecology is in a state of chain." & $\begin{array}{l}\text { The transfer of food and energy from } \\
\text { primary producers to primary, } \\
\text { secondary... consumers and } \\
\text { saprophytes defined as a food chain, } \\
\text { and many food chains occur } \\
\text { spontaneously in nature (Uzun, } \\
2016 \text { ). }\end{array}$ & $\begin{array}{l}\text { In ecological (natural) systems or } \\
\text { ecosystems, there are different } \\
\text { numbers and shapes of food chains. } \\
\text { Ecology also examines these food } \\
\text { chains. }\end{array}$ \\
\hline Community & $\begin{array}{l}\text { "The coexistence of different living things in } \\
\text { the ecological area constitutes the } \\
\text { community." }\end{array}$ & $\begin{array}{l}\text { The group that is associated with } \\
\text { each other in the same region by } \\
\text { combining multiple populations is } \\
\text { called community (Görür, 2011). }\end{array}$ & $\begin{array}{l}\text { A group of organisms that live } \\
\text { in a particular area and are in a } \\
\text { relationship with each other form the } \\
\text { community by combining more than } \\
\text { one living population. }\end{array}$ \\
\hline
\end{tabular}

In Table 2, the sentences of teacher candidates related to ecology are selected and categorized according to the concepts they contain. The literature about the sentences was examined and then the literature about the sentences written by the teacher candidates was compared. When the sentences of teacher candidates related to ecology are examined, it is seen that correct descriptions are found but in many of them there is incomplete information or concept confusion. According to Table 2, when we look at the words teacher candidates write about ecology, environment, living, balance, nature, habitat, life, science, ecosystem, human, population, cycle, food chain, animal, plant, interaction, relationship, order, chain, and community, it is observed that they bring these concepts to the fore and associate them with ecology. With the order of these concepts, the environment, living, life and balance have been associated with ecology by the teacher candidates and these concepts were expressed as the most in different sentences.

\section{Conclusion and Discussion}

Each of the 127 science teachers participating in the study was asked to write five keywords related to ecology. So a 
total of 635 responses were obtained. However, $476(75 \%)$ of these responses were associated with ecology and 159 $(25 \%)$ were not associated.

When we look at the frequency table, it was observed that the key words that teacher candidates associate most with ecology are living places with $\mathrm{f}=41(29.6 \%)$; functional properties of ecology with $\mathrm{f}=118(24.8 \%)$ and biotic factors of ecosystems in ecology with $\mathrm{f}=101(21.2 \%)$. The number and type of responses given to a stimulus in the WAT are considered an important sign of understanding this concept (Bahar, Johnstone, and Sutcliffe, 1999; Atasoy, 2004). Therefore, it can be said that the perceptions of the participants about ecology are more relevant to these upper concepts. However, the higher the total frequency of the responses given can be interpreted as a closer relationship between the ecology and living environment factors in the mental schemes of the teachers' candidates.

When viewed from the concept networks related to ecology, based on their response to the mental processes of the teachers' candidates, the first keyword associated with ecology was determined to be environment, as in figure 1. The conceptual networks in figure 2 and figure 3 were then formed, where the important keywords were the live and balance.

The cutting point range is set to five, and in this case nine conceptual networks are created. In the first cognitive networks, there is one keyword for each concept, and from figure 4, the networks have started to expand and the keywords have started to increase. Figure 9 revealed the conceptual network of teacher candidates with regard to ecology in their mental processes as a result.

According to a study conducted by Pınar and Akdağ (2012), social studies teacher candidates used the words "live", "environment", "relationship", "science", "world", "ecosystem", "balance" and "functioning" when describing the concept of ecology. In their study with the science teacher candidates of Özata Yücel and Özkan (2014), teachers' candidates stated the words "nature", "forest", "ecosystem", "world", "habitat", "population" and "species" as ecological concepts. In the study conducted by Güneş and Gözüm (2013) with the 10th grade students, "ecology", "species", "biotic factors", "food chain", "decomposer", "community", "substance cycle", "abiotic factors", "climate", "soil", "food network" and "bacteria" were determined by the students as related concepts. It is observed that these concepts associated with ecology have also emerged in this study with science teacher candidates.

Even if some of the teachers candidates who associate the concept of ecology with the environment have made the right definitions, in many, missing or misconceptions have been identified. The concepts of environment, living, life and balance are associated with ecology by teacher candidates and are expressed as maximum in different ways. This situation is important in terms of the relationship between ecology and the concepts of environment, living, life and balance. However, the use of such a different expression shows that there is a correct, incomplete or misconception in the cognitive structure of teacher candidates regarding these concepts. Some of the teacher candidates expressed ecology as a branch of science that only examined living beings, only animals and only plants. Teacher candidates used the concept of ecology to replace for the concepts of ecological (natural) systems, ecosystem and even ecological life in general and formed sentences in this way. They have ignored that ecology is a branch of science. In this sense, a confusion about concept has emerged. It has been determined that there is a complexity of the concept in relation to species, habitat and biotope concepts with each other and with ecology. In addition, it has been observed that the concepts of Ecology and environmental science are considered as the same concepts by teacher candidates. When the literature is examined, the English counterpart of the term "environmental science" for Turkish is used as "çevre bilimi". It seems that the term "ekoloji" in Turkish is different from the science of the term "ecology" in English. In Ecology, any living or living community is taken as the basis, while the human is taken center in the environmental science (Sevgi, 2015).

\section{References}

Akman, Y., Ketenoğlu, O., Kurt, L., \& Yiğit, N. (2012). Ekolojik sentez. Ankara: Palme.

Atasoy, B. (2004). Fen öğrenimi ve ögretimi (2nd Bask1). Ankara: Asil.

Bahar, M., \& Özatlı, N. S. (2003). Kelime iletişim test yöntemi ile lise 1. sınıf öğrencilerinin canlıların temel bileşenleri konusundaki bilişsel yapılarının araştırılması. Balıkesir üniversitesi fen bilimleri enstitüsü dergisi, $5(1)$.

Bahar, M., Johnstone, A.H., \& Sutcliffe, R.G. (1999). Investigation of students' cognitive structure in elementary genetics through word association tests. Journal of biological education, 33(3), 134-141. https://doi.org/10.1080/00219266.1999.9655653 
Büyüköztürk, Ş., Çakmak, E., Kılıç, A., Karadeniz, Ş., \& Demirel, F. (2011). Bilimsel araştırma yöntemleri. Ankara: Pegem akademi.

Canbazoğlu Bilici, S. (2016). An examination of science teachers' knowledge structures towards technology. International journal of environmental \& science education, 11(5), 571-586. https://doi.org/10.12973/ijese.2016.403a

Daskolia, M., Flogaitis, E., \& Papageorgiou, E. (2006). Kindergarten teachers' conceptual framework on the ozone layer depletion. Exploring the associative meanings of a global environmental issue. Journal of science education and technology, 15(2), 168-178. https://doi.org/10.1007/s10956-006-9004-8

Dikmenli, M. (2010). Biology student teachers' conceptual frameworks regarding biodiversity. Education, 130(3), 479-489.

Ekici, G., \& Kurt, H. (2014). Öğretmen adaylarının “aids” kavramı konusundaki bilişsel yapıları: bağımsız kelime ilişkilendirme testi örneği. Türkiye sosyal araştırmalar dergisi, 183, 267-306.

Ercan, F., Taşdere, A., \& Ercan, N. (2010). Kelime ilişkilendirme testi aracılığıyla bilişsel yapının ve kavramsal değişimin gözlenmesi. Türk fen eğitimi dergisi, 7(2), 136-154.

Erdoğan, M. (2016). Çevre eğitiminin doğuşu ve gelişimine kaynaklık eden hareketler ve çalışmalar. In Aysel Aydın Kocaeren (Ed.), Çevre ve enerji (s. 21-39). Ankara: Nobel.

Gökmen, S., Kubanç, N., Kubanç, C., \& Ateş Sönmezoğlu, Ö. (2011). Karasal ekoloji. In Sabri Gökmen (Ed.), Genel ekoloji (2. basım) (s. 1-20). Ankara: Nobel

Görür, G. (2011). Temel ekolojik kavramlar. In Sabri Gökmen (Ed.), Genel ekoloji (2nd basım) (s. 1-20). Ankara: Nobel.

Güleryüz, G., Arslan, H., \& Gökçeoğlu, M. (2008). Biyo-jeokimyasal Döngüler. Kani Işık (Eugene P. Odum and Gary W. Barrett (2005) Fundamentals of Ecology (5th Ed.). In Kitabının Çev. (Ed.), Ekolojinin Temel Illkeleri. Ankara: Palme.

Güneş, H., \& Gözüm, A.İ.C. (2013). İlköğretimde işlenen ekoloji konusunun 10. sinıf öğrencilerin ekosistem ekolojisi konusundaki hazırbulunuşluk düzeyleri üzerindeki etkisinin saptanmasında kelime ilişkilendirmenin kullanılması. Eğitim ve ö̆retim araştırmaları dergisi, 2(3), 240-252.

Işsk, K. (2008). Ekolojinin Konusu ve Kapsamı. Kani Işsk (Eugene P. Odum and Gary W. Barrett (2005) Fundamentals of Ecology (5th Ed.). In Kitabının Çev. (Ed.), Ekolojinin Temel İlkeleri. Ankara: Palme.

Karasar, N. (2002). Bilimsel araştırma yöntemi (11th basım). Ankara: Nobel.

Kaya, B., \& Akış, B. (2015). Coğrafya öğrencilerinin hava kavramıyla ilgili bilişsel yapılarının kelime ilişkilendirme testi ile belirlenmesi [determination of cognitive structure of geography students'on weather concept through word association test]. Turkish studies, 10(7), 557-574. https://doi.org/10.7827/TurkishStudies.8166

Kaya, N., \& Işık, K. (2008). Populasyon Ekolojisi. Kani Işık (Eugene P. Odum and Gary W. Barrett (2005) Fundamentals of Ecology (5th.Ed.). In Kitabının Çev. (Ed.), Ekolojinin Temel İlkeleri. Ankara: Palme.

Kazanc1, M., Doğan Bora, N., \& Katırcığlu, H. (2005). Investigation of meaningfull level of meiosis within students by word association test. Eurasian journal of educational research (EJER), 21, 146-154.

Kışlalıoğlu, M., \& Berkes, F. (1990). Ekoloji ve Çevre Bilimleri. İstanbul: Remzi.

Kıyıcı, G. (2009). Ekoloji. In Vahdettin sevinç (Ed.), Eğitim fakülteleri için genel çevre bilimi (s. 47-74). Ankara: Maya Akademi.

Kocataş, A. (2012). Ekoloji Çevre Biyolojisi. Bursa: Dora.

Kostova, Z., \& Radoynovska, B. (2008). Word association test for studying conceptual structures of teachers and students. Bulgarian journal of science and education policy, 2(2), 209-231.

Kurtaslan, Z. (2018). İlkokul öğrencilerinin kelime ilişkilendirme testi ile "nota" kavramı konusundaki bilişsel yapılarının belirlenmesi, Fine arts, 13(4), 77-90. https://doi.org/10.12739/NWSA.2018.13.4.D0217

Nakiboğlu, C. (2008). Using word associations for assessing nonmajor science students' knowledge structure before and after general chemistry instruction: the case of atomic structure. Chemistry education research and practice, 9, 309-322. https://doi.org/10.1039/B818466F

Öner Armağan, F. (2015). Cognitive structures of elementary school students: what is science?. European journal of 
physics education, 6(2), 54-73. https://doi.org/10.20308/ejpe.17882

Özata, E., \& Özkan, Y. M. (2014). Fen bilimleri öğretmen adaylarının çevre algılarının kelime ilişkilendirme arac1lığıyla belirlenmesi. E-international journal of educational research, 5(4), 41-56.

Pınar, A., \& Akdağ, H. (2012). Social studies teacher trainees' comprehension level of climate, wind, temperature, precipitation, erosion, ecology and map concepts. Ilköğretim online, 11(2), 530-542.

Sevgi, O. (2015). Ecology Teriminin Türkçe Karşılıkları Üzerine Bir Değerlendirme. Avrasya Terim Dergisi, 3(1), 27-46.

Ürey, M., Şahin, B., \& Şahin, N. F. (2011). Öğretmen adaylarının temel ekoloji kavramları ve çevre sorunları konusundaki yanılgıları. Ege eğitim dergisi, 1(12), 22-51.

Uzun, N. (2016). Çevre öğeleri ve sistemler. In Aysel Aydın Kocaeren (Ed.), Çevre ve enerji (s. 41-59). Ankara: Nobel.

Yıldırım, A., \& Şimşek H. (2013). Sosyal bilimlerde nitel araştırma yöntemleri. Ankara: Seçkin.

Yurtsever, S. (2011). Popülasyon ekolojisi. In Sabri Gökmen (Ed.), Genel ekoloji (2nd Basım) (s. 257-301). Ankara: Nobel. 